\title{
Ammatillinen aikuiskoulutus puun ja kuoren välissä
}

JAKSOLLA 1985-88 TOIMIN koulutussuunnittelun neuvottelukunnan sihteeristössä. Teimme erilaisia skenaariotyyppisiä laskelmia neuvottelukunnan arvioitavaksi. Kuningasajatuksemme oli sisällyttää ammatillinen aikuiskoulutus osaksi koulutuksen mitoituspäätöstä seuraaville 15 vuodelle. Aikeillamme oli neuvottelukunnan tuki, eivätkä laskennalliset lähtökohdatkaan kovin ongelmallisilta näyttäneet.

Mutta sitten tuli rimakauhu ja sen jälkeen 1990-luvun alun syvä lama. Alkoi puhe koulutusmarkkinoista, koulutuksen kysyntää ja tarjontaa ohjaavista voimista. Tämä markkinalähtöinen koulutuspuhe asetti kyseenalaiseksi koulutussuunnittelun periaatteen. Ja niinähän sitten kävi, että 1990-luvun loppuun mennessä koulutussuunnittelun neuvottelukunta oli supistunut laaja-alaisesta ja puolijulkisesta kehittelyalustasta muutaman virkamiehen ammatilliseksi vastuualueeksi.

Vaihtoehtoisista skenaarioista ei enää keskusteltu - ei ainakaan siinä laajuudessa ja yhtä kunnianhimoisesti kuin edesmenneessä neuvottelukunnassa. Jos jotakin pitkäjänteisempää ja kokeilevampaa tehtiin, se tehtiin erillisenä hanketyönä. Hankkeilla oli alku, kuten toimeksianto, josta aika hyvällä tarkkuudella saattoi ennustaa myös lopun, sen mitä tultaisiin esittämään. Siinä välissä ei ollut oikeastaan mitään mahdollisuuksia kyseenalaistaa toiminnan lähtökohtia, kuten sitä, miksi aikuiskoulutuksen asema hankkeissa jää niin fragmentaariseksi.

Näin sen ainakin itse, jo kauan sitten muihin tehtäviin siirtyneenä ekonomistina käsitin.

\section{KOULUTUSMÄÄRÄT LASKUSUUNNASSA}

Tämä käsitys vaikutti 2000-luvun puolessa välissä myös siihen, että valitsin ammatillisen aikuiskoulu- tuksen väitöskirjani aiheeksi. Väitökseni varsinainen fokus oli aikuiskoulutuksen palkkavaikutus, mutta siihen päästäkseni minun oli tietysti "vakioitava" se tausta, josta tulokset nousevat. Muuten tulokset ja niiden vertailu muissa, koulutusjärjestelmältään erilaisissa maissa saatuihin tuloksiin olisivat olleet heikolla pohjalla.

Syntyi käsitys hukatusta mahdollisuudesta. Se omaehtoinen aikuiskoulutus, jonka laajentamista 1980-luvun lopulla suunnittelimme, ei ollut lähtenyt lentoon. Jaksolla 1990-2006 sen osuus sekä aikuiskoulutustapahtumista että aikuiskoulutuspäivistä oli supistunut. Vastaavasti työnantajan maksaman henkilöstökoulutuksen osuus oli kasvanut.

Vuonna 2006 henkilöstökoulutus kattoi noin 90 prosenttia kaikista koulutustapahtumista. Ja, kuten kaikki aikuiskoulutustutkimuksen tuloksiin perehtyneet tietävät, vuoden 2000 jälkeen aikuiskoulutus (mukaan lukien henkilöstökoulutus) on kääntynyt laskuun ${ }^{1}$. Vuonna 2012 koulutusmäärät olivat likimain samalla tasolla kuin 1990. Ympyrä oli sulkeutunut.

\section{MIKSI NÄIN?}

Syyt aikuiskoulutuksen supistumiseen eivät ole vain kotoperäisiä. Myös EU:lla on lusikkansa sopassa, erityisesti henkilöstökoulutuksen osalta. 1990-luvulla EU:ssa yleistyivät näkemykset, joiden mukaan hyvä työsuhdeturva on talouskasvun jarru. 2000-luvun alkupuolella tämä näkemys sisällytettiin myös EU:n uuteen työmarkkinamalliin, joustoturvaan. Joustoturvassa ajattelu etenee joustoista turvaan, ei toisin päin. Joustoturvan rautalankamallissa joustot käynnistävät talouskasvun, jolla turva - jos niin päätetään - lopuksi rahoitetaan.

Kriittinen kysymys, josta myös itse olen aika paljon kirjoittanut, kuuluu: mikä motiivi työnantajalla 
on enää työpaikan muutostilanteessa kouluttaa ihmisiä uusiin tehtäviin? Eikö helpompaa olisi vain irtisanoa, ja jättää uudelleenkoulutus valtion huoleksi?

Tähän kysymykseen joustoturva ei suoraan vastaa. Mutta epäsuorasti, hyvää työsuhdeturvaa mollaamalla, se vastaa, että pihalle vaan. Ja näin on myös tapahtunut, erityisesti vuonna 2008 alkaneen "laantuman" aikana ${ }^{2}$. Eivätkä tyhjän kukkaron diktatuurissa elävät valtiot ole tietenkään pystyneet henkilöstökoulutuksen supistumista kompensoimaan. Koulutuksesta on päinvastoin leikattu.

\section{TULEVAISUUDESSA KAKSI SKENAARIOTA}

Itse näen kaksi vaihtoehtoista skenaariota. Ensimmäisessä Suomen työmarkkinamalli muotoutuu joustoturvan mukaiseksi joustokoneeksi, jossa aidosti laadullisilla asioilla, kuten työsuhdeturvan heikentäminen, käydään kauppaa aidosti määrällisistä tavoitteista, kuten uusien työpaikkojen ja ulkomaisten investointien määrä.

Toisessa, vaihtoehtoisessa skenaariossa tavoitteeksi asetetaan uusi (eurooppalainen) työmarkkinamalli, jossa laadullisia asioita ei alisteta määrällisille olettamille. Uusi työmarkkinamalli perustuu hyvään työsuhdeturvaan, kuten siihen että työpaikan muutostilanteessa ensisijaisia tehtäviä ovat kouluttaminen uusiin tehtäviin.

Tätä kirjoittaessani arvelen, että ensimmäinen "kauhuskenaario" on todennäköinen kehityspolkumme tästä eteenpäin. Mutta järki, sellaisena kuin sen itse koen, puhuu vahvasti jälkimmäisen, uuteen työmarkkinamalliin perustuvan skenaarion puolesta.

Väitöskirjani tulosten mukaan aikuiskoulutuksen palkkavaikutus on todella hyvä ja selvästi parempi kuin nuorisoasteen koulutuksessa. Tulosteni mukaan yksi, keskimäärin noin viikon mittainen kurssi ammatillista aikuiskoulusta nostaa bruttokuukausi- palkkaa noin 1,5 prosenttia. Se on paljon verrattuna siihen, että yksi lisävuosi nuorisoasteen koulutuksessa nostaa palkkaa "vain" 5-8 prosenttia ${ }^{3}$.

Siihen, että ammatillisesta aikuiskoulutuksesta palkitaan näin hyvin, on varmasti omat tuotannolliset syynsä. Alan kirjallisuudessa elää myös vahvana käsitys, että seuraava suuri tuottavuushyppäys perustuu siihen neuvokkuuteen, jolla kullakin työpaikalla olevat ihmiset, heidän osaamisensa ja sen kehittäminen nivotaan yhteen niiden koneiden ja laitteiden kanssa, jota sillä työpaikalla on käytössä. Kiinteä pääoma ja inhimillinen pääoma itsessään eivät enää talouskasvua kannattele, mutta niiden interaktio voi hyvinkin kannatella.

Itse olen vakuuttunut, että tämä kehityspolku tulee aikanaan yleisesti valituksi. Mutta seuraavien 10 vuoden aikana emme tätä muutosta ilmeisesti Suomessa tule vielä näkemään.

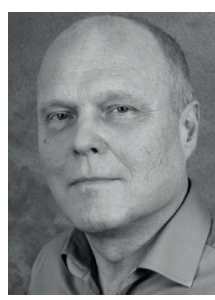

Erkki Laukkanen

KTT, ekonomisti

SAK

\section{VIITTEET:}

1. http://tilastokeskus.fi/til/aku/2012/01/ aku_2012_01_2013-06-13_tie_001_fi.html (27.3.2015).

2. https://www.etui.org/Publications2/Policy-Briefs/ European-Economic-and-Employment-Policy/ Not-for-bad-weather-flexicurity-challenged-by-thecrisis (27.3.2015).

3. http://personal.inet.fi/koti/erkki_laukkanen/thesis. pdf (27.3.2015). 